\title{
Evaluation of Nano Based Biopesticides against $S$. litura on Groundnut
}

\author{
M. Gayathri ${ }^{1 *}$, N.C. Venkateswarlu ${ }^{1}$ and T. MuraliKrishna ${ }^{2}$ \\ ${ }^{1}$ Department of Entomology, S.V. Agricultural College, Tirupati 517502, India \\ ${ }^{2}$ KVK, Kalyandurg, Ananthapur district, 515761, India \\ *Corresponding author
}

\section{A B S T R A C T}

\begin{tabular}{|l|}
\hline K e y w or d s \\
Biopesticides, $S$. \\
litura, Groundnut, \\
Bt, Barley
\end{tabular}

\section{Introduction}

Groundnut (Arachis hypogea) is one of the principal oilseed crops grown in tropical and subtropical region of the world. The tobacco caterpillar, Spodoptera litura (F.), has been reported as one of the major insect pest of groundnut and feed on 112 cultivated food plants all over the world (Mousa et al., 1980) of which 40 are grown in India (Basu, 1981; Muthukrishnan et al., 2005). It passes through 5-6 overlapping generations annually (Sasidharan and Varma, 2005; Kumar and Chapman, 2006) and if not controlled timely, it may causes in huge crop losses ranging from 25.8-100 percent in various parts of India (Ahmad et al., 2005). The management of $S$. litura using insecticides has become difficult because of the development of resistance and effect to non-target organisms viz., natural enemy population as well as frequent use of these insecticides increasing problems of human health and environmental pollution. Biological control of insect pests is one of the most important component of Integrated Pest Management (IPM), wherein entomopathogens such as bacteria, viruses and fungi are exploited against insect pests.

The insecticidal bacterium Bacillus thuringiensis $(B t)$ has been employed globally for insect pest management on several crops. It has proven itself to be a valuable tool for the control of lepidopteran insects on vegetables, cotton, soybean, hardwood and coniferous forests. Entomopathogenic fungi are potential 
agents for pest control due to their specificity, mode of action and ease of application.

Vimaladevi et al., (2005) reported that Nomuraearileyi (Farlow) Samsonand is one of the cosmopolitan occurrence primarily infecting Lepidoptera and particularly the economically important, polyphagous noctuid pests. Beauveriabassianais the causative agent of the white muscardine disease of many insect species and has been extensively used for the control of many important pests of various crops around the world (Varma and Morales 1996). The bioefficacy of entomopathogens in relation to colony forming units (cfu) in $B t$, number of conidia in $N$. rileyi and $B$. bassiana were chance to increase the bioefficacy with respect to the mortality of lepidopteran larvae by adding minerals. These minerals are namely calcium, magnesium, iron and zinc will enhance the cfu in $B t$, conidial count in $N$. rileyi as well as B.bassiana. As a result the efficacy of entomopathogns will increase and also there is a chance to decrease the dose of biopesticides. Nanoparticles are atomic or molecular aggregates characterized by size less than $100 \mathrm{~nm}$. These are actually modified form of basic elements derived by altering their atomic as well as molecular properties of elements (Suchea, et al., 2006). To enhance the biopesticides efficacy in terms of increasing the number of spores in $B t$, as well as conidial number in $N$. rileyi and $B$. bassiana the mineral salts viz., Calcium, magnesium, iron and zinc were added to the media before inoculation (Valicente et al., 2010). By considering all these issues the present studies were carried out.

\section{Materials and Methods}

Preparation of nanoparticulate solutions

Oxide nanoparticles of $\mathrm{Zn}, \mathrm{Ca}, \mathrm{Mg}$ and $\mathrm{Fe}$ weighing $250 \mathrm{mg}$ was added to $500 \mathrm{ml}$ of

distilled water $(500 \mathrm{ppm})$ and from this solution different concentrations $(100,50,20$ and $10 \mathrm{ppm}$ ) of nanoparticulate solutions were prepared by adding the respective volumes of distilled water.

From the prepared nanoparticulate solutions $\mathrm{Zn}, \mathrm{Fe}, \mathrm{Ca}$ and $\mathrm{Mg}$ at $10 \mathrm{ppm}, 20 \mathrm{ppm}, 50$ $\mathrm{ppm}, 100 \mathrm{ppm}$ and $500 \mathrm{ppm}$ in $1: 9$ ratio $(1 \mathrm{ml}$ of nanoparticulate solution to $9 \mathrm{ml}$ of LBA media) was added to the Luria Bertani Agar media before sterilisation to study the catalytic activity of nanomaterials on the Bacillus thuringiensis. Similarly the nanoparticles of $\mathrm{Zn}, \mathrm{Fe}, \mathrm{Ca} \& \mathrm{Mg}$ at the same concentrations were added to Sabouraud Maltose Agar media (SMAY) and Sabouraud Dextrose Agar medeia (SDAY) media before sterilisation to study their activity on growth and multiplication of $N$. rileyi and B. bassiana.

These nano enriched biopesticides were tested against S. litura larvae under laboratory conditions. The concentrations of nanomaterial enriched biopesticides which were proved effective were evaluated under field conditions against $S$. litura on groundnut.

Assessment of viability of $B t$, Nomuraea and Beauveria with Carriers

Preparation of solid formulations of $B$. thuringiensis with the composition of Barley flour solid media grown under nanomaterial based media

Components

$\begin{array}{ll}\text { Barley } & 5 \mathrm{~g} \\ \text { Yeast extract } & 63 \mathrm{~g} \\ \mathrm{CaCl}_{2} & 24 \mathrm{~g} \\ \mathrm{MgSO}_{4} & 60 \mathrm{mg} \\ \mathrm{K}_{2} \mathrm{HPO}_{4} & 50 \mathrm{mg} \\ \mathrm{KH}_{2} \mathrm{PO}_{4} & 50 \mathrm{mg} \\ \text { Water } & 50 \mathrm{ml}\end{array}$




\section{Media preparation}

Five grams of barley flour was taken in a 250 $\mathrm{ml}$ conical flask. Simultaneously yeast extract, $\mathrm{CaCl}_{2}, \quad \mathrm{MgSO}_{4}, \quad \mathrm{~K}_{2} \mathrm{HPO}_{4}$ and $\mathrm{KH}_{2} \mathrm{PO}_{4}$ ingredients were dissolved separately in $50 \mathrm{ml}$ distilled water and this was added to already prepared barley in conical flask. The $\mathrm{p}^{\mathrm{H}}$ of the medium was adjusted to 7.2 and the flasks containing media were sterilized at 15 psi for 20 minutes, cooled and inoculated with $2 \%$ (v/v) of $B t$ multiplied on Luria broth and incubated for $48 \mathrm{~h}$ at $30^{\circ} \mathrm{C}$ on a shaker at 200 rpm. The medium from flasks was centrifuged, the pellet was dried in a laminar air flow and used for field application (Vimaladevi et al., 2005) (Plate 9).

Preparation of solid formulations of $N$. rileyi and $B$. bassiana with the composition of Broken rice and Talcused as solid media grown under nanomaterial based media

\section{Media preparation with broken rice}

One hundred grams of broken rice was washed, drained and soaked in water for $3 \mathrm{~h}$ before starting the experiment. The excess of water was drained by decanting and shade dried for half an hour to remove the excess moisture. The substrates were packed separately in individual autoclaved at $15 \mathrm{psi}$ for $50 \mathrm{~min}$. After autoclaving, the substrates were cooled at room temperature and preserved in the refrigerator till further use. These substrates were inoculated individually with Nomuraea and B. bassiana (Lingappa and Patil, 2002) (Plate 10).

\section{Media preparation with talc}

SMAY broth was used for the production of $N$. rileyi spores in $100 \mathrm{ml}$ conical flasks. The sterilized broth was inoculated with spores of $N$. rileyi and incubated at $20 \pm 5{ }^{\circ} \mathrm{C}$ temperature and $85 \% \mathrm{RH}$ in constant temperature and humidity controlled chamber for 20 days. The conidial strength per $\mathrm{ml}$ of broth was assessed and the wettable powder was prepared mixing talc powder as a carrier material to obtain strength of $2 \times 10^{8}$ conidia per ml of spray solution (Mallikarjuna et al., 2010).

\section{Field experiment}

The experiment was conducted during the period of 2016-17 and 2017-18 rabi season to evaluate the efficacy of these nanomaterial based biopesticides under field conditions at Dry land farm, S. V. Agricultural College, Tirupati after standardization of bio-pesticides against $S$. litura through bioassay method under laboratory conditions during the year 2016 and 2017 at Department of Entomology, IFT, RARS, Tirupati.

\section{Field preparation}

The land was thoroughly ploughed thrice and levelled uniformly. Recommended doses of fertilizers i.e. nitrogen $\left(10 \quad \mathrm{~kg} \mathrm{ha}^{-1}\right)$, phosphorus $\left(40 \mathrm{~kg} \mathrm{ha}^{-1}\right)$, potassium $(16 \mathrm{~kg}$ $\mathrm{ha}^{-1}$ ) were applied as basal application and gypsum $\left(500 \mathrm{~kg}^{-1}\right)$ applied at the time of peg formation. Manual weeding was taken up at 20 and 40 days after sowing.

\section{Seed treatment and layout}

Groundnut seed was treated with mancozeb @ $3 \mathrm{~g} / \mathrm{kg}$ seed to protect the crop from soil and seed borne diseases. The experiment was laid out in randomized block design. Individual plot size was $3 \times 5 \mathrm{~m}$ with the spacing of 30 $\mathrm{cm}$ between rows and $10 \mathrm{~cm}$ plant to plant (Plate 12).

\section{Spraying}

The standardised nanomaterial based biopesticides against S.litura under laboratory 
conditions were prepared with different formulations and sprayed on groundnut for the management of S.litura at 45 to 50 days after sowing to know the efficacy under field conditions.

\section{Data recorded on}

Pre count of the S.litura larvae was taken before spraying.

Post count of the S.litura larvae was taken at 3, 7 and 10 days after spraying.

Per cent damage was recorded at 7 days and 14 days after spraying.

\section{Harvest of the crop}

The groundnut crop was harvested at 110 days after sowing by manual pulling, simultaneously stripping of the pods and dried under shade conditions.

Fresh weight, dry weight of the pod and also dry weight of the haulm was recorded as $\mathrm{kg} /$ plot and converted into per hectare.

\section{Results and Discussion}

Field trials were conducted during rabi, 201617 and 2017-18 for testing the efficacy of solid formulations of effective nanomaterial based $B$. thuringiensis, $N$. rileyi and $B$. bassiana against $S$. liturain groundnut. A total of twenty six treatments along with untreated control were sown in randomized block design with two replications by including all the three biopesticides. Groundnut crop was sown during rabi season in both years as per the agronomic practices recommended by ANGRAU.

B. thuringiensis grown in nanoparticles based media were inoculated to barley based solid formulations containing spores, cells and crystal suspensions. Similarly N.rileyi, B.bassiana grown under nanoparticles based media were also inoculated to rice and talc based solid formulations and allowed to grow. These formulations were sprayed @ 2g per litre when the defoliation was observed above economic threshold level $(25 \%)$ in groundnut. The composition of spray fluid containing mixture of robin blue @ $1 \mathrm{ml} \mathrm{L}^{-1}$ as UV protectant, jaggery @ 2g/liter as feeding additive, Bt@1 $\mathrm{g} \mathrm{L}^{-1}$ in solid formulation was sprayed when $S$. litura larvae was observed and foliage damage exceeded 25 per cent at 50 days after sowing. Triton-X @ $2 \mathrm{ml} \mathrm{L}^{-1}$ was added as emulsifying agent.

The observations were recorded on S. litura population at one day before treatment and 3 and 7 days after spraying (DAS) on 10 plants randomly selected in both the replications. The per cent foliar damage was recorded one day before spray as pre-treatment count and at 7 and 14 days after spraying as post treatment. The pod yield $\left(\mathrm{kg} \mathrm{ha}^{-1}\right)$ and haulm yield $(\mathrm{kg}$ $\mathrm{ha}^{-1}$ ) were recorded after harvesting of the crop.

Field efficacy of nanomaterial based biopesticides against $S$. lituraon groundnut larval population

Observations were recorded on S.litura larvae before and after treatment of the nanomaterial based biopesticides with regular intervals during 2016. The pre-count of S.litura larvae was recorded one day before treatment and it was ranged from 19.50 to 25.50 no./10 plants in different plots laid for evaluating the nanomaterial based biopesticides. The results revealed that population was reduced after application of these biopesticides. The third day after treatment, the mean per cent reduction was ranged from 0.00 to 77.00 per cent. The highest per cent mean population reduction was recorded (77.00) in treatment $\mathrm{CaO}$ at $20 \mathrm{ppm}$ based $B t$ formulations $\left(\mathrm{T}_{3}\right)$ followed by 66.7 per cent with $\mathrm{MgO}$ at $50 \mathrm{ppm}$ $\left(\mathrm{T}_{4}\right)$ based $B t$ formulations, 57.9 per cent with 
$\mathrm{FeO}$ at 50ppm $\left(\mathrm{T}_{2}\right)$ based $B t$ formulations and 47.8 per cent $\mathrm{ZnO}$ at $20 \mathrm{ppm}\left(\mathrm{T}_{1}\right)$ based $B t$ formulations. Similarly in $B t$ without nanomaterial treatment $\left(\mathrm{T}_{21}\right)$ it was 45.96 per cent where as in control the mean per cent reduction was 0.00 . The larval count was reduced in all treatments except untreated control at 3 days after spray. Lowest larval population was recorded in $\mathrm{CaO}$ at $20 \mathrm{ppm}$ $\left(\mathrm{T}_{3}\right)$ based $B t$ (5.5 larva/10 plants) and $\mathrm{MgO}$ at 50ppm $\left(\mathrm{T}_{1}\right)$ based $B t$. In untreated control, the larval population was 21.5 larva/10 plants. The mean per cent reduction 7 days after spraying was ranged from 0 to 75 per cent. The highest mean per cent reduction was 75 in $\mathrm{CaO}$ based B. bassiana talc formulations $\left(\mathrm{T}_{19}\right)$, followed by 68.44 per cent in $\mathrm{CaO}$ based $N$.rileyi broken rice formulations $\left(\mathrm{T}_{21}\right)$. Ten days after spraying the mean per cent reduction was ranged from -12.5 to 15.8 per cent (Table 1).

Observations were recorded on the larval population of S.litura before treatment and after treatments of the nanomaterial based biopesticides at $3^{\text {rd }}, 7^{\text {th }}$ and $10^{\text {th }}$ days after spraying duringrabi2017. The pre-count of S.litura larval population was ranged from 20.5 to $26.5 / 10$ plants in different plots laid for evaluating the nanomaterial based biopesticides. Studies revealed that the population was reduced after application of these biopesticides. The third day after treatment, the population was ranged from 0.0 to 74.44 per cent. The mean S.itura population was observed to be reduced to the extent of 74.44 per cent in treatments $\mathrm{CaO}$ based $\mathrm{Bt}$ formulations $\left(\mathrm{T}_{3}\right)$ followed by 66.60 per cent with $\mathrm{MgO}$ based $B t$ formulations $\left(\mathrm{T}_{4}\right), 58.35$ per cent with $\mathrm{FeO}$ based $B t$ formulations $\left(\mathrm{T}_{2}\right)$ and 54.76 per cent $\mathrm{ZnO}$ based $B t$ formulations $\left(\mathrm{T}_{1}\right)$. Similarly in $B t$ without nanomaterial treatment $\left(\mathrm{T}_{21}\right)$ it was 45.96 per cent where as in control the mean per cent reduction was 0.00 . The larval count was reduced in all treatments except untreated control at 7 days after spray. The lowest larval population was recorded in $\mathrm{CaO}$ and $\mathrm{MgO}$ based $\mathrm{Bt}\left(\mathrm{T}_{3}\right.$ and $\mathrm{T}_{4}$ respectively) (4.5 larva/10 plants), followed by $\mathrm{FeO}$ and $\mathrm{ZnO}$ based $B t\left(\mathrm{~T}_{2}\right.$ and $\mathrm{T}_{1}$ respectively) (5.5 larva/10 plants). In untreated control, the larval population was 19.5 larva/10 plants. The mean per cent reduction of $S$. litura larva at 7 days after spraying was ranged from 0.00 to 73.72 per cent. The highest mean per cent reduction was 73.72 in $\mathrm{CaO}$ based $B$. bassiana talc formulations $\left(\mathrm{T}_{21}\right)$, followed by 68.44 per cent in $\mathrm{CaO}$ based $N$. rileyi broken rice formulations $\left(\mathrm{T}_{15}\right)$. Ten days after spraying the mean per cent reduction was ranged from 0.00 to 16.67 per cent (Table 2).

\section{Foliar damage}

The data on foliar damage due to S.litura was recorded from different treatments at one day before spray, 7 and 14 days after spray. The results indicated that one day before spray, the foliar damage due to S.litura was ranged from 29.69 to 41.36 per cent in different plots during rabi, 2016 and34.42 to 43.61 per cent in rabi, 2017 (Table 3 and 4).

\section{At 7 DAS}

At seven days after spray, the foliar damage due to $S$. litura in groundnut was ranged from 17.01 to 32.10 per cent in different plots treated with nanomaterial based $B t, N$.rileyi and B.bassiana solid formulations. Bt grown on barley flour and with $\mathrm{CaO}$ nanoparticles was found as effective treatment $\left(\mathrm{T}_{3}\right)$ with lowest damage of 16.73 per cent defoliation followed by $B t$ grown on barley flour and with $\mathrm{MgO}$ nanoparticles $\left(\mathrm{T}_{4}\right)(17.01 \%)$ which were superior over the other treatments and statistically on par with each other. The other treatments viz., N.rileyi with $\mathrm{CaO}$ nanomaterial based broken rice formulation $\left(\mathrm{T}_{7}\right)(17.35 \%)$, B.bassiana $\mathrm{CaO}$ nanomaterial based talc formulation $\left(\mathrm{T}_{19}\right)(20.78 \%)$. In 
untreated control, the foliar damage was 32.10 per cent in rabi 2016.

Similarly, during 2017 rabi also the above mentioned treatments were found effective in recording the lowest per cent defoliation $14.76 \% B t$ grown on barley flour and with $\mathrm{CaO}$ nanoparticles was found as effective treatment with lowest damage of per cent defoliation followed by $B t$ grown on barley flour and with $\mathrm{MgO}$ nanoparticles (16.48\%) which were superior over the other treatments and statistically on par with each other. The other treatments viz., N.rileyi with $\mathrm{CaO}$ nanopartical broken rice formulation (17.17\%), B.bassiana with $\mathrm{CaO}$ nanoparticle talc formulation $(17.85 \%)$.

\section{At 14 DAS}

Fourteen days after spray, foliar damage was ranged from 5.6 to 33.83 per cent in different treatments. $B t$ grown on barley flour and with $\mathrm{CaO}$ nanoparticles was found as effective treatment $\left(\mathrm{T}_{3}\right)$ with lowest damage of 5.6 per cent defoliation followed by $B t$ grown on barley flour and with $\mathrm{MgO}$ nanoparticles $\left(\mathrm{T}_{4}\right)$ (6.2\%) which were superior over the other treatments and statistically on par with each other.

The other treatments viz., N.rileyi with $\mathrm{CaO}$ nanoparticle in broken rice formulation $\left(\mathrm{T}_{5}\right)$ (7.3\%), B.bassiana $\mathrm{CaO}$ nanoparticle talc formulation $\left(\mathrm{T}_{19}\right)(7.4 \%)$ were on par with each other. The foliar damage was reduced in other $B t$ treated plots also at a considerable level, but there was not much variation in their efficacy levels at 7 days after treatment and 14 days after treatment, whereas, the foliar damage was 33.83 per cent in untreated control during rabi, 2016.

During 2017, fourteen days after spray, the foliar damage due to S.litura was ranged from 3.96 to 38.20 per cent in different treatments. $B t$ grown on barley flour with $\mathrm{CaO}$ nanoparticles $\left(T_{3}\right)$ was found to be effective treatment with lowest damage of 3.96 per cent defoliation followed by $B t$ grown on barley flour and with $\mathrm{MgO}$ nanoparticles $\left(\mathrm{T}_{4}\right)$ $(4.76 \%)$ which were superior over the other treatments and statistically on par with each other. The other treatments viz., N. rileyi with $\mathrm{CaO}$ nanoparticle in broken rice formulation $\left(\mathrm{T}_{7}\right)(5.98 \%)$, B.bassiana $\mathrm{CaO}$ nanoparticle talc formulation $\left(\mathrm{T}_{19}\right)(6.91 \%)$ were on par with each other. The foliar damage was reduced in other $B t$ treated plots also at a considerable level, but there was not much variation in their efficacy levels at 7 days after treatment and 14 days after treatment, whereas, the foliar damage was 38.20 per cent in untreated control.

\section{Pod yield}

Pod yield was recorded at the time of harvest during the year 2016 and 2017. The data on pod yield in solid formulations of $B t$ strains was in the range of 896 to $1919 \mathrm{~kg} \mathrm{ha}^{-1}$. The results indicated that $B t$ grown on barley flour and with $\mathrm{CaO}$ nanoparticles was found as effective treatment with highest pod yield of $1993 \mathrm{~kg} \mathrm{ha}^{-1}$ followed by $B t$ grown on barley flour with $\mathrm{MgO}$ nanoparticles $1919 \mathrm{~kg} \mathrm{ha}^{-1}$ which were superior over the other treatments and statistically on par with each other. In untreated control, pod yield was $896 \mathrm{~kg} \mathrm{ha}^{-1}$ (Table 3).

During 2017, the pod yield in solid formulations of $B t$ strains was in the range of 911 to $2022 \mathrm{~kg} \mathrm{ha}^{-1}$. Bt grown on barley flour with $\mathrm{CaO}$ nanoparticles was found as effective treatment $\left(\mathrm{T}_{3}\right)$ with highest pod yield of (2022 $\mathrm{kg} \mathrm{ha}^{-1}$ ) followed by $B t$ grown on barley flour with $\mathrm{MgO}$ nanoparticles $\left(\mathrm{T}_{4}\right)\left(1933 \mathrm{~kg} \mathrm{ha}^{-1}\right)$ which were superior over the other treatments and statistically on par with each other. In untreated control $\left(\mathrm{T}_{26}\right)$, pod yield was $911 \mathrm{~kg}$ ha $^{-1}$ (Table 4). 
Table.1 Field efficacy of different nano based biopesticides against $S$. litura in groundnut during rabi 2016

\begin{tabular}{|c|c|c|c|c|c|c|c|c|}
\hline \multirow{2}{*}{$\begin{array}{l}\text { S. } \\
\text { No. }\end{array}$} & \multirow{2}{*}{ Name of the Treatment } & \multicolumn{4}{|c|}{ Larval count/10 plants } & \multicolumn{3}{|c|}{ Mean \% reduction } \\
\hline & & Pre treatment & 3 DAS & 7 DAS & 10 DAS & 3 DAS & 7 DAS & 10 DAS \\
\hline 1. & $\begin{array}{l}\text { T1 ( } B t \text { grown on barley flour and } \\
\text { with } \mathrm{Zn} \text { nanoparticle }\end{array}$ & 23.00 & 9.50 & 7.50 & 5.50 & $\begin{array}{c}47.8 \\
(43.75)\end{array}$ & $\begin{array}{c}8.7 \\
(17.15)\end{array}$ & $\begin{array}{c}8.7 \\
(17.51)\end{array}$ \\
\hline 2. & $\begin{array}{l}\text { T2 (Bt grown on barley flour and } \\
\text { with Fe nanoparticle) }\end{array}$ & 24.00 & 10.50 & 6.50 & 4.50 & $\begin{array}{c}57.9 \\
(49.54)\end{array}$ & $\begin{array}{c}16.7 \\
(24.09)\end{array}$ & $\begin{array}{c}8.3 \\
(16.78)\end{array}$ \\
\hline 3. & $\begin{array}{l}\text { T3 ( } B t \text { grown on barley flour and } \\
\text { with Ca nanoparticle) }\end{array}$ & 20.00 & 8.50 & 5.50 & 3.50 & $\begin{array}{c}77.0 \\
(61.34)\end{array}$ & $\begin{array}{c}15.0 \\
(22.79)\end{array}$ & $\begin{array}{c}10.0 \\
(18.43)\end{array}$ \\
\hline 4. & $\begin{array}{l}\mathrm{T} 4 \text { ( } B t \text { grown on barley flour and } \\
\text { with } \mathrm{Mg} \text { nanoparticle) }\end{array}$ & 21.00 & 11.50 & 6.50 & 4.50 & $\begin{array}{c}66.7 \\
(54.74)\end{array}$ & $\begin{array}{c}23.8 \\
(29.21)\end{array}$ & $\begin{array}{c}9.5 \\
(17.98)\end{array}$ \\
\hline 5. & $\begin{array}{l}\text { T5 (Nomuraea grown on broken rice } \\
\text { and with } \mathrm{Zn} \text { nanoparticle) }\end{array}$ & 22.00 & 21.50 & 13.50 & 12.50 & $\begin{array}{c}2.3 \\
(8.67)\end{array}$ & $\begin{array}{c}36.4 \\
(37.09)\end{array}$ & $\begin{array}{c}4.5 \\
(12.31)\end{array}$ \\
\hline 6. & $\begin{array}{l}\text { T6 (Nomuraea grown on broken rice } \\
\text { and with Fe nanoparticle) }\end{array}$ & 23.50 & 23.00 & 12.50 & 10.50 & $\begin{array}{c}0.0 \\
(0.00)\end{array}$ & $\begin{array}{c}47.8 \\
(43.75)\end{array}$ & $\begin{array}{c}8.7 \\
(17.15)\end{array}$ \\
\hline 7. & $\begin{array}{l}\text { T7(Nomuraea grown on broken rice } \\
\text { and with Ca nanoparticle) }\end{array}$ & 22.50 & 22.00 & 9.50 & 7.50 & $\begin{array}{c}0.0 \\
(0.00)\end{array}$ & $\begin{array}{c}63.2 \\
(52.65)\end{array}$ & $\begin{array}{c}9.5 \\
(17.98)\end{array}$ \\
\hline 8. & $\begin{array}{l}\text { T8 (Nomuraea grown on broken rice } \\
\text { and with Mg nanoparticle) }\end{array}$ & 25.50 & 25.00 & 11.50 & 8.50 & $\begin{array}{c}0.0 \\
(0.00)\end{array}$ & $\begin{array}{c}58.3 \\
(49.80)\end{array}$ & $\begin{array}{l}12.5 \\
(20.7)\end{array}$ \\
\hline 9. & $\begin{array}{l}\text { T9 (Nomuraea grown on talc and } \\
\text { with Zn nanoparticle) }\end{array}$ & 23.00 & 22.50 & 11.50 & 10.50 & $\begin{array}{c}0.0 \\
(0.00)\end{array}$ & $\begin{array}{l}47.8 \\
(43.75)\end{array}$ & $\begin{array}{c}4.3 \\
(12.04)\end{array}$ \\
\hline 10. & $\begin{array}{l}\text { T10 (Nomuraea grown on talc and } \\
\text { with Fe nanoparticle) }\end{array}$ & 23.00 & 21.50 & 9.50 & 8.50 & $\begin{array}{c}0.0 \\
(0.00)\end{array}$ & $\begin{array}{c}53.33 \\
(46.91)\end{array}$ & $\begin{array}{c}4.8 \\
(12.6)\end{array}$ \\
\hline 11. & $\begin{array}{l}\text { T11 (Nomuraea grown on talc and } \\
\text { with Ca nanoparticle) }\end{array}$ & 22.50 & 22.00 & 5.50 & 4.50 & $\begin{array}{c}0.0 \\
(0.00)\end{array}$ & $\begin{array}{c}58.7 \\
(50.01)\end{array}$ & $\begin{array}{c}5.0 \\
(12.92)\end{array}$ \\
\hline 12. & $\begin{array}{l}\text { T12 (Nomuraea grown on talc and } \\
\text { with Mg nanoparticle) }\end{array}$ & 19.50 & 19.00 & 8.50 & 6.50 & $\begin{array}{c}0.0 \\
(0.00)\end{array}$ & $\begin{array}{c}57.5 \\
(49.31)\end{array}$ & $\begin{array}{c}10.5 \\
(18.93)\end{array}$ \\
\hline 13. & $\begin{array}{l}\text { T13 (Beauveria grown on broken } \\
\text { rice and with Zn nanoparticle) }\end{array}$ & 22.50 & 22.00 & 13.50 & 10.50 & $\begin{array}{c}0.0 \\
(0.00)\end{array}$ & $\begin{array}{c}45.0 \\
(42.13)\end{array}$ & $\begin{array}{c}15.0 \\
(22.79)\end{array}$ \\
\hline 14. & $\begin{array}{l}\text { T14 (Beauveria grown on broken } \\
\text { rice and with Fe nanoparticle) }\end{array}$ & 23.50 & 21.00 & 11.50 & 9.50 & $\begin{array}{c}0.0 \\
(0.00)\end{array}$ & $\begin{array}{c}57.1 \\
(49.11)\end{array}$ & $\begin{array}{c}9.5 \\
(17.98)\end{array}$ \\
\hline 15. & $\begin{array}{l}\text { T15 (Beauveria grown on broken } \\
\text { rice and with Ca nanoparticle) }\end{array}$ & 23.50 & 23.00 & 8.50 & 5.50 & $\begin{array}{c}0.0 \\
(0.00)\end{array}$ & $\begin{array}{c}61.9 \\
(51.89)\end{array}$ & $\begin{array}{c}13.6 \\
(21.67)\end{array}$ \\
\hline 16. & $\begin{array}{l}\text { T16 (Beauveria grown on broken } \\
\text { rice and with Mg nanoparticle) }\end{array}$ & 20.50 & 20.00 & 9.50 & 7.50 & $\begin{array}{c}0.0 \\
(0.00)\end{array}$ & $\begin{array}{c}61.1 \\
(51.42)\end{array}$ & $\begin{array}{c}11.1 \\
(19.47)\end{array}$ \\
\hline 17. & $\begin{array}{l}\text { T17 (Beauveria grown on talc and } \\
\text { with Zn nanoparticle) }\end{array}$ & 22.50 & 22.00 & 10.50 & 8.50 & $\begin{array}{c}0.0 \\
(0.00)\end{array}$ & $\begin{array}{c}45.2 \\
(42.27)\end{array}$ & $\begin{array}{c}10.0 \\
(18.43)\end{array}$ \\
\hline 18. & $\begin{array}{l}\text { T18 (Beauveria grown on talc and } \\
\text { with Fe nanoparticle) }\end{array}$ & 20.50 & 20.00 & 9.50 & 6.50 & $\begin{array}{c}0.0 \\
(0.00)\end{array}$ & $\begin{array}{c}42.9 \\
(40.89)\end{array}$ & $\begin{array}{c}15.8 \\
(23.41)\end{array}$ \\
\hline 19. & $\begin{array}{l}\text { T19 (Beauveria grown on talc and } \\
\text { with Ca nanoparticle) }\end{array}$ & 23.00 & 22.00 & 5.50 & 4.50 & $\begin{array}{c}0.0 \\
(0.00)\end{array}$ & $\begin{array}{c}75.0 \\
(60.00)\end{array}$ & $\begin{array}{c}4.5 \\
(12.31)\end{array}$ \\
\hline 20. & $\begin{array}{l}\text { T20 (Beauveria grown on talc and } \\
\text { with Mg nanoparticle) }\end{array}$ & 21.50 & 21.00 & 8.50 & 6.50 & $\begin{array}{c}0.0 \\
(0.00)\end{array}$ & $\begin{array}{c}61.9 \\
(51.89)\end{array}$ & $\begin{array}{c}9.5 \\
(17.98)\end{array}$ \\
\hline 21. & T21 (Bt grown on talc) & 22.00 & 9.50 & 15.50 & 13.50 & $\begin{array}{c}45.2 \\
(42.27)\end{array}$ & $\begin{array}{c}7.3 \\
(15.68)\end{array}$ & $\begin{array}{c}9.1 \\
(17.55)\end{array}$ \\
\hline 22. & T22 (Nomuraea grown on talc) & 24.00 & 23.50 & 18.50 & 17.50 & $\begin{array}{c}0.0 \\
(0.00)\end{array}$ & $\begin{array}{c}26.1 \\
(30.71)\end{array}$ & $\begin{array}{c}4.3 \\
(12.04)\end{array}$ \\
\hline 23. & $\begin{array}{l}\text { T23 (Nomuraea grown on broken } \\
\text { rice) }\end{array}$ & 23.00 & 22.50 & 13.50 & 11.50 & $\begin{array}{c}0.0 \\
(0.00)\end{array}$ & $\begin{array}{c}50.0 \\
(45.00)\end{array}$ & $\begin{array}{c}10.0 \\
(18.43)\end{array}$ \\
\hline 24. & T24 (Beauveria grown on talc) & 22.50 & 22.00 & 12.50 & 10.50 & $\begin{array}{c}0.0 \\
(0.00)\end{array}$ & $\begin{array}{c}45.5 \\
(42.39)\end{array}$ & $\begin{array}{c}9.1 \\
(17.55)\end{array}$ \\
\hline 25. & $\begin{array}{l}\text { T25 (Beauveria grown on broken } \\
\text { rice) }\end{array}$ & 23.00 & 22.50 & 14.50 & 12.50 & $\begin{array}{c}0.0 \\
(0.00)\end{array}$ & $\begin{array}{c}42.9 \\
(40.89)\end{array}$ & $\begin{array}{c}9.5 \\
(17.98)\end{array}$ \\
\hline 26. & T26 (control (water spray)) & 20.00 & 20.00 & 21.50 & 22.50 & $\begin{array}{c}0.0 \\
(0.00)\end{array}$ & $\begin{array}{c}-7.5 \\
(15.89)\end{array}$ & $\begin{array}{l}-12.5 \\
(20.00)\end{array}$ \\
\hline & F pr. & $<0.05$ & $<0.05$ & $<0.05$ & $<0.05$ & & & - \\
\hline
\end{tabular}

Figures in parentheses are arcsine transformed values 
Table.2. Field efficacy of different nano based biopesticides against $S$. litura in groundnut during rabi 2017

\begin{tabular}{|c|c|c|c|c|c|c|c|c|}
\hline \multirow{2}{*}{$\begin{array}{l}\text { S. } \\
\text { No. }\end{array}$} & \multirow[t]{2}{*}{ Name of the Treatment } & \multicolumn{4}{|c|}{ Larval count $/ 10$ plants } & \multicolumn{3}{|c|}{ Mean \% reduction } \\
\hline & & Pre treatment & 3 DAS & 7 DAS & 10 DAS & 3 DAS & 7 DAS & 10 DAS \\
\hline 1. & $\begin{array}{l}\mathrm{T}_{1} \text { (Bt grown on barley flour and with } \\
\mathrm{Zn} \text { nanoparticle }\end{array}$ & 24.50 & 8.00 & 5.50 & 3.50 & $\begin{array}{c}54.76 \\
(47.23)\end{array}$ & $\begin{array}{c}31.25 \\
(33.99)\end{array}$ & $\begin{array}{c}6.66 \\
(14.96)\end{array}$ \\
\hline 2. & $\begin{array}{l}\mathrm{T}_{2} \text { (Bt grown on barley flour and with } \mathrm{Fe} \\
\text { nanoparticle) }\end{array}$ & 26.50 & 9.00 & 5.50 & 3.50 & $\begin{array}{c}58.35 \\
(55.15)\end{array}$ & $\begin{array}{c}38.89 \\
(38.58)\end{array}$ & $\begin{array}{c}16.36 \\
(23.86)\end{array}$ \\
\hline 3. & $\begin{array}{c}\mathrm{T}_{3} \text { (Bt grown on barley flour and with } \\
\text { Ca nanoparticle) }\end{array}$ & 21.50 & 7.00 & 4.50 & 2.50 & $\begin{array}{c}74.44 \\
(66.77)\end{array}$ & $\begin{array}{c}35.71 \\
(36.70)\end{array}$ & $\begin{array}{c}14.44 \\
(22.33)\end{array}$ \\
\hline 4. & $\begin{array}{l}\mathrm{T}_{4} \text { (Bt grown on barley flour and with } \\
\text { Mg nanoparticle) }\end{array}$ & 23.50 & 10.00 & 4.50 & 2.50 & $\begin{array}{c}66.60 \\
(54.33)\end{array}$ & $\begin{array}{c}55.00 \\
(47.87)\end{array}$ & $\begin{array}{c}14.44 \\
(22.33)\end{array}$ \\
\hline 5. & $\begin{array}{l}\mathrm{T}_{5} \text { (Nomuraea grown on broken rice and } \\
\text { with } \mathrm{Zn} \text { nanoparticle) }\end{array}$ & 23.00 & 19.00 & 12.50 & 11.00 & $\begin{array}{c}17.39 \\
(24.65)\end{array}$ & $\begin{array}{c}34.21 \\
(35.80)\end{array}$ & $\begin{array}{c}12.00 \\
(20.27)\end{array}$ \\
\hline 6. & $\begin{array}{l}\mathrm{T}_{6} \text { (Nomuraea grown on broken rice and } \\
\text { with Fe nanoparticle) }\end{array}$ & 25.00 & 22.50 & 10.50 & 9.00 & $\begin{array}{l}10.00 \\
(18.43)\end{array}$ & $\begin{array}{c}53.33 \\
(46.91)\end{array}$ & $\begin{array}{c}7.5 \\
(15.89)\end{array}$ \\
\hline 7. & $\begin{array}{l}\mathrm{T}_{7} \text { (Nomuraea grown on broken rice and } \\
\text { with Ca nanoparticle) }\end{array}$ & 24.00 & 21.00 & 8.50 & 6.50 & $\begin{array}{l}12.50 \\
(20.7)\end{array}$ & $\begin{array}{c}68.44 \\
(55.80)\end{array}$ & $\begin{array}{l}13.53 \\
(21.62)\end{array}$ \\
\hline 8. & $\begin{array}{c}\mathrm{T}_{8} \text { (Nomuraea grown on broken rice and } \\
\text { with } \mathrm{Mg} \text { nanoparticle) }\end{array}$ & 25.00 & 23.50 & 10.50 & 7.00 & $\begin{array}{c}6.00 \\
(14.18)\end{array}$ & $\begin{array}{c}55.32 \\
(48.05)\end{array}$ & $\begin{array}{c}13.33 \\
(21.42)\end{array}$ \\
\hline 9. & $\begin{array}{l}\mathrm{T}_{9} \text { (Nomuraea grown on talc and with } \\
\mathrm{Zn} \text { nanoparticle) }\end{array}$ & 26.00 & 21.00 & 9.50 & 8.50 & $\begin{array}{c}19.23 \\
(26.01)\end{array}$ & $\begin{array}{c}43.18 \\
(41.08)\end{array}$ & $\begin{array}{c}10.53 \\
(18.93)\end{array}$ \\
\hline 10. & $\begin{array}{l}\mathrm{T}_{10} \text { (Nomuraea grown on talc and with } \\
\text { Fe nanoparticle) }\end{array}$ & 22.00 & 21.50 & 8.50 & 7.50 & $\begin{array}{c}2.27 \\
(8.67)\end{array}$ & $\begin{array}{c}45.00 \\
(42.13)\end{array}$ & $\begin{array}{c}11.76 \\
(20.06)\end{array}$ \\
\hline 11. & $\begin{array}{l}\mathrm{T}_{11} \text { (Nomuraea grown on talc and with } \\
\text { Ca nanoparticle) }\end{array}$ & 22.00 & 21.50 & 5.50 & 3.00 & $\begin{array}{c}2.27 \\
(8.67)\end{array}$ & $\begin{array}{c}65.12 \\
(53.80)\end{array}$ & $\begin{array}{l}14.29 \\
(22.21)\end{array}$ \\
\hline 12. & $\begin{array}{l}\mathrm{T}_{12} \text { (Nomuraea grown on talc and with } \\
\text { Mg nanoparticle) }\end{array}$ & 21.50 & 17.50 & 7.50 & 5.00 & $\begin{array}{l}18.60 \\
(25.55)\end{array}$ & $\begin{array}{c}57.14 \\
(49.11)\end{array}$ & $\begin{array}{l}13.33 \\
(21.41)\end{array}$ \\
\hline 13. & $\begin{array}{l}\mathrm{T}_{13} \text { (Beauveria grown on broken rice } \\
\text { and with } \mathrm{Zn} \text { nanoparticle) }\end{array}$ & 21.50 & 20.50 & 12.50 & 9.00 & $\begin{array}{c}4.65 \\
(12.45)\end{array}$ & $\begin{array}{c}39.02 \\
(38.66)\end{array}$ & $\begin{array}{c}8.00 \\
(16.43)\end{array}$ \\
\hline 14. & $\begin{array}{l}\mathrm{T}_{14} \text { (Beauveria grown on broken rice } \\
\text { and with Fe nanoparticle) }\end{array}$ & 23.00 & 22.50 & 9.50 & 8.00 & $\begin{array}{c}2.17 \\
(8.48)\end{array}$ & $\begin{array}{c}45.00 \\
(42.13)\end{array}$ & $\begin{array}{c}15.79 \\
(23.41)\end{array}$ \\
\hline 15. & $\begin{array}{c}\mathrm{T}_{15} \text { (Beauveria grown on broken rice } \\
\text { and with Ca nanoparticle) }\end{array}$ & 23.50 & 21.50 & 7.50 & 4.50 & $\begin{array}{c}8.51 \\
(16.96)\end{array}$ & $\begin{array}{c}59.52 \\
(50.49)\end{array}$ & $\begin{array}{c}10.00 \\
(18.43)\end{array}$ \\
\hline 16. & $\begin{array}{l}\mathrm{T}_{16} \text { (Beauveria grown on broken rice } \\
\text { and with } \mathrm{Mg} \text { nanoparticle) }\end{array}$ & 20.50 & 19.00 & 7.50 & 5.50 & $\begin{array}{c}7.32 \\
(15.69)\end{array}$ & $\begin{array}{c}60.53 \\
(51.08)\end{array}$ & $\begin{array}{l}16.67 \\
(24.10)\end{array}$ \\
\hline 17. & $\begin{array}{l}\mathrm{T}_{17} \text { (Beauveria grown on talc and with } \\
\text { Zn nanoparticle) }\end{array}$ & 22.00 & 20.50 & 9.50 & 7.00 & $\begin{array}{c}6.82 \\
(15.14)\end{array}$ & $\begin{array}{c}45.00 \\
(42.13)\end{array}$ & $\begin{array}{c}6.67 \\
(14.91)\end{array}$ \\
\hline 18. & $\begin{array}{l}\mathrm{T}_{18} \text { (Beauveria grown on talc and with } \\
\text { Fe nanoparticle) }\end{array}$ & 20.50 & 19.00 & 8.50 & 5.50 & $\begin{array}{c}7.32 \\
(15.69)\end{array}$ & $\begin{array}{c}45.96 \\
(42.68)\end{array}$ & $\begin{array}{r}15.29 \\
(23.02)\end{array}$ \\
\hline 19. & $\begin{array}{l}\mathrm{T}_{19} \text { (Beauveria grown on talc and with } \\
\text { Ca nanoparticle) }\end{array}$ & 24.00 & 22.50 & 5.00 & 5.00 & $\begin{array}{c}6.25 \\
(14.48)\end{array}$ & $\begin{array}{c}73.72 \\
(58.82)\end{array}$ & $\begin{array}{c}14.29 \\
(22.21)\end{array}$ \\
\hline 20. & $\begin{array}{l}\mathrm{T}_{20} \text { (Beauveria grown on talc and with } \\
\text { Mg nanoparticle) }\end{array}$ & 22.50 & 19.00 & 7.50 & 5.00 & $\begin{array}{l}15.56 \\
(23.23)\end{array}$ & $\begin{array}{c}60.53 \\
(51.08)\end{array}$ & $\begin{array}{c}13.33 \\
(21.41)\end{array}$ \\
\hline 21. & $\mathrm{~T}_{21}(B t$ grown on talc) & 23.50 & 8.00 & 13.50 & 11.50 & $\begin{array}{c}45.96 \\
(42.68)\end{array}$ & $\begin{array}{c}0.0 \\
(0.00)\end{array}$ & $\begin{array}{c}14.81 \\
(22.64)\end{array}$ \\
\hline 22. & $\mathrm{~T}_{22}$ (Nomuraea grown on talc) & 25.50 & 24.50 & 17.50 & 16.50 & $\begin{array}{c}9.80 \\
(18.25)\end{array}$ & $\begin{array}{c}23.91 \\
(29.28)\end{array}$ & $\begin{array}{c}5.71 \\
(13.83)\end{array}$ \\
\hline 23. & $\mathrm{~T}_{23}$ (Nomuraea grown on broken rice) & 22.00 & 21.00 & 12.50 & 10.50 & $\begin{array}{l}0.0 \\
(0.00)\end{array}$ & $\begin{array}{c}43.18 \\
(41.08)\end{array}$ & $\begin{array}{l}16.00 \\
(23.58)\end{array}$ \\
\hline 24. & $\mathrm{~T}_{24}$ (Beauveria grown on talc) & 24.50 & 21.00 & 10.50 & 8.50 & $\begin{array}{c}14.29 \\
(22.21)\end{array}$ & $\begin{array}{c}45.00 \\
(42.13)\end{array}$ & $\begin{array}{c}19.05 \\
(25.88)\end{array}$ \\
\hline 25. & $\mathrm{~T}_{25}$ (Beauveria grown on broken rice) & 23.00 & 21.00 & 13.50 & 11.00 & $\begin{array}{c}8.70 \\
(17.15)\end{array}$ & $\begin{array}{c}35.71 \\
(36.70)\end{array}$ & $\begin{array}{c}18.52 \\
(25.49)\end{array}$ \\
\hline 26. & $\mathrm{~T}_{26}$ (control (water spray)) & 21.50 & 21.50 & 22.50 & 22.00 & $\begin{array}{c}0.0 \\
(0.00)\end{array}$ & $\begin{array}{c}1.0 \\
(5.74)\end{array}$ & $\begin{array}{c}0.5 \\
(4.05)\end{array}$ \\
\hline & $\mathrm{F}$ & $<0.05$ & $<0.05$ & $<0.05$ & $<0.05$ & & & \\
\hline
\end{tabular}

Figures in parentheses are arcsine transformed values 
Table.3. Field efficacy of different nano based biopesticides against S.litura in groundnut during rabi2016

\begin{tabular}{|c|c|c|c|c|c|c|}
\hline \multirow[t]{2}{*}{ S.No. } & \multirow[t]{2}{*}{ Name of the Treatment } & \multicolumn{3}{|c|}{ \% Defoliation in 2016} & \multirow{2}{*}{$\begin{array}{c}\text { Pod yield } \\
\text { (kg/ha) } \\
2016\end{array}$} & \multirow{2}{*}{$\begin{array}{c}\text { Haulm yield } \\
\text { (kg/ha) } \\
2016\end{array}$} \\
\hline & & Pre treatment & 7 DAS & 14 DAS & & \\
\hline 1. & $\begin{array}{l}\text { T1 (Bt grown on barley flour and with } \mathrm{Zn} \\
\text { nanoparticle }\end{array}$ & $38.28(38.22)$ & $20.91(27.21)$ & $8.2(16.64)$ & 1786 & 3560 \\
\hline 2. & $\begin{array}{l}\mathrm{T} 2 \text { (Bt grown on barley flour and with } \mathrm{Fe} \\
\text { nanoparticle) }\end{array}$ & $39.35(38.85)$ & $20.18(26.69)$ & $7.5(15.89)$ & 1840 & 3667 \\
\hline 3. & $\begin{array}{l}\text { T3 (Bt grown on barley flour and with } \mathrm{Ca} \\
\text { nanoparticle) }\end{array}$ & $36.54(37.19)$ & $17.01(24.36)$ & $5.6(13.69)$ & 1993 & 3899 \\
\hline 4. & $\begin{array}{l}\text { T4 (Bt grown on barley flour and with } \mathrm{Mg} \\
\text { nanoparticle) }\end{array}$ & $33.55(35.39)$ & $17.35(24.62)$ & $6.2(14.42)$ & 1919 & 3828 \\
\hline 5. & $\begin{array}{l}\text { T5 (Nomuraea grown on broken rice and with } \mathrm{Zn} \\
\text { nanoparticle) }\end{array}$ & $33.22(35.20)$ & $21.79(27.83)$ & $15.7(23.34)$ & 1386 & 2763 \\
\hline 6. & $\begin{array}{l}\text { T6 (Nomuraea grown on broken rice and with Fe } \\
\text { nanoparticle) }\end{array}$ & $38.27(38.21)$ & $26.03(30.68)$ & $14.6(22.46)$ & 1473 & 2935 \\
\hline 7. & $\begin{array}{l}\mathrm{T} 7 \text { (Nomuraea grown on broken rice and with } \mathrm{Ca} \\
\text { nanoparticle) }\end{array}$ & $33.69(35.48)$ & $20.78(27.12)$ & $7.4(15.79)$ & 1934 & 3256 \\
\hline 8. & $\begin{array}{l}\mathrm{T} 8 \text { (Nomuraea grown on broken rice and with } \mathrm{Mg} \\
\text { nanoparticle) }\end{array}$ & $34.17(35.77)$ & $24.46(29.64)$ & $12.8(20.96)$ & 1574 & 3136 \\
\hline 9. & $\begin{array}{l}\text { T9 (Nomuraea grown on talc and with } \mathrm{Zn} \\
\text { nanoparticle) }\end{array}$ & $36.68(37.27)$ & $27.53(31.65)$ & $16.1(23.66)$ & 1482 & 2951 \\
\hline 10. & $\begin{array}{l}\text { T10 (Nomuraea grown on talc and with Fe } \\
\text { nanoparticle) }\end{array}$ & $33.83(35.56)$ & $26.65(31.08)$ & $15.0(22.79)$ & 1580 & 3150 \\
\hline 11. & $\begin{array}{l}\text { T11 (Nomuraea grown on talc and with } \mathrm{Ca} \\
\text { nanoparticle) }\end{array}$ & $35.12(36.35)$ & $21.51(27.63)$ & $9.1(17.56)$ & 1640 & 3670 \\
\hline 12. & $\begin{array}{l}\mathrm{T} 12 \text { (Nomuraea grown on talc and with } \mathrm{Mg} \\
\text { nanoparticle) }\end{array}$ & $37.77(37.92)$ & $21.00(27.27)$ & $9.6(18.05)$ & 1631 & 3253 \\
\hline 13. & $\begin{array}{l}\text { T13 (Beauveria grown on broken rice and with } \mathrm{Zn} \\
\text { nanoparticle) }\end{array}$ & $32.10(34.51)$ & $25.68(30.45)$ & $14.0(21.97)$ & 1485 & 2959 \\
\hline 14. & $\begin{array}{l}\text { T14 (Beauveria grown on broken rice and with Fe } \\
\text { nanoparticle) }\end{array}$ & $35.02(36.28)$ & $28.02(31.96)$ & $16.3(23.81)$ & 1560 & 3108 \\
\hline 15. & $\begin{array}{l}\text { T15 (Beauveria grown on broken rice and with } \mathrm{Ca} \\
\text { nanoparticle) }\end{array}$ & $36.92(37.52)$ & $20.80(27.13)$ & $10.1(18.53)$ & 1696 & 3380 \\
\hline 16. & $\begin{array}{l}\text { T16 (Beauveria grown on broken rice and with } \mathrm{Mg} \\
\text { nanoparticle) }\end{array}$ & $38.61(38.41)$ & $20.78(27.12)$ & $9.1(17.56)$ & 1597 & 3181 \\
\hline 17. & $\begin{array}{l}\text { T17 (Beauveria grown on talc and with } \mathrm{Zn} \\
\text { nanoparticle) }\end{array}$ & $35.63(36.65)$ & $24.84(29.89)$ & $13.1(21.22)$ & 1423 & 2836 \\
\hline 18. & $\begin{array}{l}\text { T18 (Beauveria grown on talc and with Fe } \\
\text { nanoparticle) }\end{array}$ & $36.11(36.94)$ & $22.12(28.05)$ & $10.7(19.09)$ & 1520 & 3030 \\
\hline 19. & $\begin{array}{l}\text { T19 (Beauveria grown on talc and with } \mathrm{Ca} \\
\text { nanoparticle) }\end{array}$ & 34.87 (36.19) & $16.73(24.14)$ & $7.3(15.68)$ & 1904 & 3373 \\
\hline 20. & $\begin{array}{l}\text { T20 (Beauveria grown on talc and with } \mathrm{Mg} \\
\text { nanoparticle) }\end{array}$ & $37.39(37.61)$ & $21.03(27.29)$ & $9.3(17.76)$ & 1586 & 3161 \\
\hline 21. & $\mathrm{~T} 21$ (Bt grown on talc) & $40.11(39.29)$ & $27.43(31.58)$ & $16.0(23.58)$ & 1303 & 2594 \\
\hline 22. & T22 (Nomuraea grown on talc) & $33.92(35.62)$ & $26.38(30.90)$ & $14.7(22.54)$ & 1229 & 2446 \\
\hline 23. & T23 (Nomuraea grown on broken rice) & $41.36(40.02)$ & $29.05(32.61)$ & $17.4(24.65)$ & 1160 & 2307 \\
\hline 24. & T24 (Beauveria grown on talc) & $37.01(37.47)$ & $27.14(31.40)$ & $15.7(23.34)$ & 1220 & 2430 \\
\hline 25. & T25 (Beauveria grown on broken rice) & $39.86(39.15)$ & $27.51(31.63)$ & $15.8(23.42)$ & 1129 & 2248 \\
\hline 26. & T26 (control (water spray) & $29.69(33.02)$ & $32.10(34.51)$ & $33.83(35.56)$ & 896 & 1783 \\
\hline & C.D. & - & 4.20 & 7.06 & 20.76 & 21.53 \\
\hline & $\mathrm{SE}(\mathrm{m})$ & - & 1.43 & 2.41 & 7.08 & 7.35 \\
\hline & $\mathrm{SE}(\mathrm{d})$ & - & 2.03 & 3.41 & 10.2 & 10.39 \\
\hline & C.V. & - & 8.28 & 20.12 & 0.66 & 0.67 \\
\hline
\end{tabular}

Figures in parentheses are arcsine transformed values 
Table.4. Field efficacy of different nano based biopesticides against S.litura in groundnut during rabi2017

\begin{tabular}{|c|c|c|c|c|c|c|}
\hline \multirow{2}{*}{$\begin{array}{l}\text { S. } \\
\text { No. }\end{array}$} & \multirow[t]{2}{*}{ Name of the Treatment } & \multicolumn{3}{|c|}{ \% Defoliatioin } & \multirow{2}{*}{$\begin{array}{l}\text { Pod yield } \\
(\mathrm{kg} / \mathrm{ha})\end{array}$} & \multirow{2}{*}{$\begin{array}{l}\text { Haulm yield } \\
\text { (kg/ha) }\end{array}$} \\
\hline & & Pre treatment & 7 DAS & 14 DAS & & \\
\hline 1. & $\begin{array}{l}\mathrm{T} 1 \text { ( } B t \text { grown on barley flour and with } \mathrm{Zn} \\
\text { nanoparticle }\end{array}$ & $38.78(38.52)$ & $19.31(26.06)$ & $8.25(16.69)$ & 1806 & 3582 \\
\hline 2. & $\begin{array}{l}\mathrm{T} 2 \text { (Bt grown on barley flour and with } \mathrm{Fe} \\
\text { nanoparticle) }\end{array}$ & $41.35(40.02)$ & $19.51(26.21)$ & $7.25(15.62)$ & 1857 & 3690 \\
\hline 3. & $\begin{array}{l}\text { T3 (Bt grown on barley flour and with } \mathrm{Ca} \\
\text { nanoparticle) }\end{array}$ & $38.04(38.08)$ & $14.76(22.59)$ & $3.96(11.48)$ & 2022 & 4027 \\
\hline 4. & $\begin{array}{l}\mathrm{T} 4 \text { ( } B t \text { grown on barley flour and with } \mathrm{Mg} \\
\text { nanoparticle) }\end{array}$ & $40.55(39.55)$ & $16.65(24.08)$ & $4.76(12.60)$ & 1933 & 3851 \\
\hline 5. & $\begin{array}{l}\text { T5 (Nomuraea grown on broken rice and with } \\
\text { Zn nanoparticle) }\end{array}$ & $37.22(37.60)$ & $26.50(30.98)$ & $14.30(22.22)$ & 1401 & 2786 \\
\hline 6. & $\begin{array}{l}\text { T6 (Nomuraea grown on broken rice and with } \\
\text { Fe nanoparticle) }\end{array}$ & $42.27(40.55)$ & $25.74(30.49)$ & $12.68(20.86)$ & 1496 & 2958 \\
\hline 7. & $\begin{array}{l}\text { T7(Nomuraea grown on broken rice and with } \\
\text { Ca nanoparticle) }\end{array}$ & $37.19(37.58)$ & $17.17(24.48)$ & $5.98(14.15)$ & 1948 & 3279 \\
\hline 8. & $\begin{array}{l}\text { T8 (Nomuraea grown on broken rice and with } \\
\text { Mg nanoparticle) }\end{array}$ & $34.67(36.07)$ & $23.11(28.73)$ & $11.47(19.80)$ & 1594 & 3158 \\
\hline 9. & $\begin{array}{l}\text { T9 (Nomuraea grown on talc and with } \mathrm{Zn} \\
\text { nanoparticle) }\end{array}$ & $38.68(38.46)$ & $26.38(30.90)$ & $14.63(22.49)$ & 1499 & 2974 \\
\hline 10. & $\begin{array}{l}\text { T10 (Nomuraea grown on talc and with Fe } \\
\text { nanoparticle) }\end{array}$ & $35.33(36.47)$ & $25.50(30.33)$ & $13.30(21.39)$ & 1595 & 3174 \\
\hline 11. & $\begin{array}{l}\text { T11 (Nomuraea grown on talc and with Ca } \\
\text { nanoparticle) }\end{array}$ & $42.12(40.47)$ & $19.08(25.90)$ & $7.68(16.09)$ & 1954 & 3693 \\
\hline 12. & $\begin{array}{l}\text { T12 (Nomuraea grown on talc and with } \mathrm{Mg} \\
\text { nanoparticle) }\end{array}$ & $41.77(40.26)$ & $19.15(25.95)$ & $8.25(16.69)$ & 1646 & 3276 \\
\hline 13. & $\begin{array}{l}\text { T13 (Beauveria grown on broken rice and } \\
\text { with Zn nanoparticle) }\end{array}$ & $36.10(36.93)$ & $25.53(30.35)$ & $12.04(20.30)$ & 1508 & 2982 \\
\hline 14. & $\begin{array}{l}\text { T14 (Beauveria grown on broken rice and } \\
\text { with Fe nanoparticle) }\end{array}$ & $38.52(38.36)$ & $27.62(31.70)$ & $14.47(22.36)$ & 1574 & 3131 \\
\hline 15. & $\begin{array}{l}\text { T15 (Beauveria grown on broken rice and } \\
\text { with Ca nanoparticle) }\end{array}$ & $37.42(37.71)$ & $19.30(26.06)$ & $8.81(17.27)$ & 1716 & 3403 \\
\hline 16. & $\begin{array}{l}\text { T16 (Beauveria grown on broken rice and } \\
\text { with Mg nanoparticle) }\end{array}$ & $40.61(39.59)$ & $19.17(25.96)$ & $7.58(15.98)$ & 1614 & 3203 \\
\hline 17. & $\begin{array}{l}\text { T17 (Beauveria grown on talc and with } \mathrm{Zn} \\
\text { nanoparticle) }\end{array}$ & $37.13(37.54)$ & $23.35(28.90)$ & $11.49(1981)$ & 1438 & 2860 \\
\hline 18. & $\begin{array}{l}\text { T18 (Beauveria grown on talc and with Fe } \\
\text { nanoparticle) }\end{array}$ & $43.11(41.04)$ & $21.02(27.29)$ & $9.32(17.78)$ & 1534 & 3053 \\
\hline 19. & $\begin{array}{l}\text { T19 (Beauveria grown on talc and with } \mathrm{Ca} \\
\text { nanoparticle) }\end{array}$ & $38.87(38.57)$ & $17.85(24.99)$ & $6.91(15.24)$ & 1924 & 3384 \\
\hline 20. & $\begin{array}{l}\text { T20 (Beauveria grown on talc and with } \mathrm{Mg} \\
\text { nanoparticle) }\end{array}$ & $41.39(40.04)$ & $20.51(26.93)$ & $7.38(15.76)$ & 1609 & 3185 \\
\hline 21. & T21 (Bt grown on talc) & $43.61(41.33)$ & $26.03(30.68)$ & $14.18(22.12)$ & 1317 & 2616 \\
\hline 22. & T22 (Nomuraea grown on talc) & $34.42(35.92)$ & $25.28(30.18)$ & $13.38(21.46)$ & 1249 & 2469 \\
\hline 23. & T23 (Nomuraea grown on broken rice) & $43.36(41.18)$ & $27.30(31.50)$ & $15.85(23.46)$ & 1177 & 2329 \\
\hline 24. & T24 (Beauveria grown on talc) & $38.51(38.36)$ & $25.71(30.46)$ & $14.09(22.05)$ & 1235 & 2453 \\
\hline 25. & T25 (Beauveria grown on broken rice) & $38.87(38.57)$ & $26.26(30.83)$ & $14.44(22.33)$ & 1143 & 2272 \\
\hline 26. & T26 (control (water spray)) & $35.22(36.40)$ & $36.68(37.27)$ & $38.20(38.17)$ & 911 & 1805 \\
\hline & C.D. & & 2.90 & 9.21 & 21.53 & 5.35 \\
\hline & $\mathrm{SE}(\mathrm{m})$ & & 0.99 & 3.14 & 7.35 & 1.82 \\
\hline & $\mathrm{SE}(\mathrm{d})$ & & 1.40 & 4.44 & 10.39 & 2.58 \\
\hline & C.V. & & 5.96 & 37.91 & 0.67 & 0.08 \\
\hline
\end{tabular}

Figures in parentheses are arcsine transformed values 


\section{Haulm yield}

Groundnut haulm was shade dried and dry haulm weight was recorded during the year 2016 and 2017. The dry haulm yield was ranged from 1783.0 to $3899.0 \mathrm{~kg}$ ha- 1 in different plots treated with nanomaterial based solid formulations of $B t$. The highest haulm yield was recorded in $B t$ grown on barley flour and with $\mathrm{CaO}$ nanoparticles was found with highest pod yield of (3899 $\left.\mathrm{kg} \mathrm{ha}^{-1}\right)$ followed by $B t$ grown on barley flour and with $\mathrm{MgO}$ nanoparticles $\left(3828 \mathrm{~kg} \mathrm{ha}^{-1}\right)$ which were superior over the other treatments and statistically on par with each other. In untreated control, haulm yield was $1783 \mathrm{~kg}$ $\mathrm{ha}^{-1}$ during rabi 2016.

Similarly, haulm yield was recorded duringrabi2017 and it was ranged from 1805 to $4027 \mathrm{~kg}$ ha-1 in different plots treated with nanomaterial based solid formulations of $B t$. The highest haulm yield was recorded in $B t$ grown on barley flour and with $\mathrm{CaO}$ nanoparticles was found as effective treatment with highest pod yield of $\left(4027 \mathrm{~kg} \mathrm{ha}^{-1}\right)$ followed by $B t$ grown on barley flour and with $\mathrm{MgO}$ nanoparticles $\left(3851 \mathrm{~kg} \mathrm{ha}^{-1}\right)$ which were superior over the other treatments and statistically on par with each other. In untreated control, haulm yield was $1783 \mathrm{~kg}$ $\mathrm{ha}^{-1}$.

Under field conditions the three tested nanomaterial based biopesticidesviz., $\quad B t$ (Vimala Devi and Vineela, 2015; Vimala Devi et al., 2005; Lalitha and Muralikrishna 2012), N. rieyi (Rao et al., 2005; Pavone et $a l ., 2009$ ) and B. bassiana (Varma and Morales 1996; Patel et al., 2014) were found effective biopesticides against $S$. litura larvae in groundnut. The significant highest per cent mortality within 3 DAS in $B t$ treated plots in both seasons while in $N$. rileyi and B.bassiana treated plots the maximum mortality was observed at 7 DAS. The significant highest pod yield and haulm yield was recorded in both the seasons treated with nanomaterial enriched biopesticides when compared with biopesticides without nanoparticles as well as control. The literature pertaining to this aspect is scarce hence further studies are needed to know the increased efficacy of biopesticides whether it could be from increased number of spores by adding minerals at nano scale or due to nanoparticles directly.

\section{References}

Ahmad, M., Saleem, M. A and Ahmad, M. 2005. Time oriented mortality in leaf army worm, Spodoptera litura (Fab.) (Lepidoptera: Noctuidae) by some new chemistry insecticides. Pakistan Entomology. 27 (1): 67-70.

Basu, A. C. 1981. Effect of different foods on the larval and post larval development of moth of Prodenia litura (Fab.).Journal of Bombay Natural History Society; 44: 275-288.

Kumar, K and Chapman, R. B. 2006. Sublethal effects of insecticides on the diamondback moth Plutella xylostella (L.). Pesticide Science. 15: 344-352.

Lalitha, C., Muralikrishna, $\mathrm{T}$ and Chalam, M.S.V. 2012. Isolation, Identification, Bioassay and Field Evaluation of Native Bacillus thuringiensis Strains against Spodoptera litura (Fabricius) in Groundnut (Arachis hypogaea). Journal of Biological control. 26 (1): 34-42.

Lingappa, $\mathrm{S}$ and Patil, R.K. 2002.Nomuraearileyi - A Potential Mycoinsecticide. University of Agricultural Sciences, Dharwad, p. 30.

Mallikarjuna, D. R., Patil, R. K., Sujay, Y. H. and Ramegowda, G.K. 2010. Development and evaluation of wettable powder and oil based formulations of Nomura earileyi (Farlow) Samson against Helicoverpa armigera (Hübner) 
and Spodoptera litura (Fabricius). Journal of Biological Control. 24 (3): 231-237.

Mousa, M. A., Zaker, M. A and Koppy, F. 1980. Abundance of cotton leaf worm, Prodenialitura (Fab.) in relation to host plants Host plants and their effect on biology. Bulletin of Entomological Society, Egypte. 44: 241-251.

Muthukrishnan, N., Ganapathy, N., Nalini, R and Rajendran, R. 2005. Pest Management in Horticultural Crops. New Madura Publishers, Madurai. Pp. 325.

Patel, A., Gaikwad,V., Ambhure, K., Saxena, A.K and Kachar, S. 2014. Evaluation of entomopathogens against lepidopteran defoliators infesting soybean. Journal of Biopesticides. 7(51):186-190.

Pavone, D., Dlaz, M., Truzillo, M and Dorta, B. 2009. A granular formulation of Nomuraearileyi Farlow (Samson) for the control of Spodoptrea frugiperda (Lepidoptera: Noctuidae). Interciencia. 34 (2): 130-134.

Rao, C.U.M., Devi, K.U and Khan, P.A.A. 2005.Effect of combination treatment with entomopathogenic fungi Beauveria bassiana and Nomuraearileyi (Hypocreales) on Spodopteralitura (Lepidoptera: Noctuidaeae). Biocontrol Science and Technology. 16 (3): 221232.

Sasidharan, K. R and Varma, R.V. 2005. Laboratory evaluation of Beauveria bassiana (Balsamo) Vuillemin against Indarbel aquadrinotata Walker (Lepidoptera: Metarbelidae) - a key pest of Casuarina equisetifolia L. in Tamil Nadu. Journal of Biological Control.19: 197- 200.

Suchea, M., Christoulakis, S., Moschovis, K., Katsarakis, N and Kiriakidis, G. 2006. $\mathrm{ZnO}$ transparent thin films for gas sensor applications. Thin Solid Films. 515: 551-554.

Valicente, F.H., Tuelher, E.D.S, Liete, M.I.S, Freire, F.L and Vieira, C.M. 2010.Production of Bacillus thuringiensis biopesticide using commercial lab medium and agricultural by-products as nutrient sources. Revista Brasileira de Milho e Sorgo. 9 (1): 1-11.

Varma, A and Morales, E. 1996. Characterization of some Beauveria bassiana isolates and their virulence toward the coffee berry borer Hypothenemu shampei. Journal of Invertebrate Pathology. 67:147-12.

Vimala Devi, P.S and Vineela, V. 2014.Suspension concentrate formulation of Bacillus thuringiensis var. kurstaki for effective management of Helicoverpa armigera on sunflower (Helianthus annuus). Biocontrol Science and Technology. 25(3): 329336.

\section{How to cite this article:}

Gayathri, M., N.C. Venkateswarlu and MuraliKrishna, T. 2018. Evaluation of Nano Based Biopesticides against S. litura on Groundnut. Int.J.Curr.Microbiol.App.Sci. 7(12): 1614-1625. doi: https://doi.org/10.20546/ijcmas.2018.712.189 